\title{
Deconstructing Contemporary Dance Discourses by Acknowledging Elderly Female Bodies
}

Annakarin Simonson

\section{ABSTRACT}

This article uses a choreographic project to discuss the relationship between elderly women and contemporary dance. It focuses on how participating in the project is of artistic value to these women and what happens in the meeting between me as a master's student and researcher, the project itself and the women. The article is based on a master's project in dance pedagogy aimed at using action to change normative ideas about a dancer's body. The artistic practice is based on the women's lived experiences. Through improvisation and with a somatic approach as a choreographic performative practice, collaborative transformative learning emerged from the participants. By articulating and visualising the experiences of elderly women as a marginalised group, the meaning of the concepts of dance, body, and age was deconstructed and new insights were gained to challenge and broaden normative ideas about dance and the dancer's body. The discoveries presented in this article show that elderly women have the capacity to change through dance. By using a decolonising methodology, I argue that deconstruction can be achieved in interactions with others and experienced as artistry. In conclusion, I claim that age norms and bodily ideals in contemporary dance discourses can be challenged by taking the advantage of the resources of older women and by giving them access to contemporary dance.

\section{ABSTRACT}

Denna artikel diskuterar relationer som uppstår i ett koreografiskt projekt mellan äldre kvinnor och samtida dans. Utgångspunkten ligger vid vilket värde projektet har för dessa kvinnor och vad som sker i mötet mellan mig som forskande masterstuderande, projektet och kvinnorna. Artikeln grundar sig i ett dansdidaktiskt masterprojekt med ambition att genom handling ändra normativa idéer om dans och kropp. Den konstnärliga praktiken baseras på kvinnornas levda erfarenhet. Med improvisation och ett somatiskt förhållningssätt som koreografisk performativ praktik har ett kollaborativt transformativt lärande uppstått mellan deltagarna. Genom att artikulera och synliggöra äldre kvinnor som marginaliserad grupp, har betydelsen av begreppen dans, kropp och ålder dekonstruerats och nya insikter har uppstått som utmanar och breddare normativa idéer om dans och kropp. De upptäckter som presenteras i artikeln visar att äldre kvinnor har kapacitet att förändras genom dans. Genom att använda dekoloniserande metodologi, argumenterar jag för att dekonstruktion kan uppstå i interaktion med andra, och upplevas som konstnärlighet. Sammanfattningsvis menar jag att åldersnormer och kroppsliga ideal inom samtida dansdiskurser kan utmanas genom att använda äldre kvinnor som resurs och göra samtida dans tillgängligt. 


\title{
Deconstructing Contemporary Dance Discourses by Acknowledging Elderly Female Bodies
}

\author{
Annakarin Simonson
}

\section{Introduction}

After many years of practicing and teaching dance, the need to use dance to express myself artistically has grown even stronger. This is something I expected would decrease as my body changed with age. When reflecting on the assumption that an ageing body would be equivalent to a reduced desire to express oneself artistically through dance, I found that this seemed to be a normal perception of the relationship between dance and age. I started asking myself how an ageing female body without virtuosity could be significant in the context of contemporary dance.

In this article, which is based on mymaster'sdegree in contemporary dance, I discuss how acknowledging the ageing female body can be considered a resource in the context of contemporary dance. I discuss how contemporary dance discourses can be deconstructed using a decolonising methodology and to what extent women experience their artistic values by dancing together.

My dance training originates from a EuroAmerican contemporary dance standpoint which is youth-oriented and focused on «ability» and «disability» of the dancer's body (Brandstetter and Nakajima 2017). Against this background, the research originates from a personal interest in age, body, and dance, as well as an ambition to disrupt contemporary dance discourses in an academic context and change normative ideas about the dancer's body (Simonson 2021). I wanted to investigate how these normative dance discourses could be problematised from a critical age perspective and explored through an action-based production of knowledge derived from dancing.
I was curious to find out the extent to which contemporary dance was valuable to elderly women with no previous dance experience, what dance could do for elderly women who do dance, and what would happen between me, the dancers, and the choreographic project I was facilitating. To examine this, I invited 13 women between 55-67 years of age to participate in a choreographic project and share embodied experiences together.

\section{A project with an activist agenda}

The project started by gathering voluntary participants. A flyer was published on social media to attract participants with a desire to express themselves artistically through dance. Curiosity, imagination, and exploration were emphasised. I named the project Women who want to DANCE., emphasising the concept of free will and action with a creative direction. The dot (.) in the title held a symbolic value in taking a stand for women who want to change through action and be part of a transformative process, including an activistic aspect (Simonson 2021, 11). There was ambition to change by using a decolonising perspective and resisting normative assumptions about women and age. To apply decolonising methodology means in this context to critically examine how the western worldview reproduces knowledge (Fensham 2008, 2-3), while also exploring new methodologies for thinking about and experiencing dance.

The participants represented themselves by resisting normative values about age and dance instead of representing assumptions of the group of 
elderly women. Consequently, the dancers were given the opportunity to re-establish their dancing bodies by articulating an artistry and dance of their own, as opposed to considering traditional norms ascribed to elderly feminine bodies.

\section{Lived Experiences as Bearer of the Project}

One of my main intentions was to highlight elderly women's experiences in the context of contemporary dance in order to distinguish dance as an artistic activity as opposed to a training activity. My intention was to provide a space to dance for the sake of the dance, thereby exploring dance and artistry without focusing on increased physical ability or achieving results. This was done to shift the focus away from the concepts of health and well-being that are usually promoted when discussing ageing and dancing (Krekula et al. 2017, 42).

Eight workshops were conducted and designed around different themes related to the body and ageing. In order to emphasise artistry, the dancers were encouraged to use their lived experience to examine their dancing. For me as the researcher, it was important to offer a safe and non-hierarchical atmosphere without judgement. By using open instructions like, «Let the skin be in contact with the air» instead of «Move your body like this,» the dancers could investigate their own personal experience and generate feelings of having and using imagination and creativity. While exploring one of the themes, to meet, the dancers and I considered the distance between the feet meeting each other and the experience of the skin meeting the air around us. To meet each other by resting in someone's gaze could be scary at first, but after a while, it created the feeling of being seen in a real and authentic manner. Being confirmed by another dancer enhanced the sense of being visible.

The workshops were built through the contribution of the lived experiences of bodily stories, emotional moods and memories. By using emotional and subjective incentives, the content of the project emerged in interaction with me and the dancers during the process. The knowledge was situated and created from the lived experiences and reflections of me and the participants. Consequently, the choreographic practice created new insights through action and doing rather than through abstract thinking. This approach acknowledges that it is not possible to separate knowledge from the situations in which it is generated (Barrett and Bolt 2010, 5).

\section{Choreography as a Performative Practice}

The dancers' intentions defined the choreographic practice, as did the relationship between the dancers and the environment. I chose this approach as an expanded way to understand the concept of choreography (Klien 2008), as a performative practice that includes the processes of thinking, writing, and dancing in collaboration as opposed to the choreographer defining a predetermined idea that controls the process.

The dancers were able to use their intuition and spontaneity to make personal choices as I used a somatic approach to guide them through structured improvisations. The somatic approach links body and mind together by including both sensory and cognitive aspects of embodied experiences (Coogan 2016; Brandstetter 2007, 41). This means that the body cannot be separated from feelings about ourselves or environmental experiences. By paying attention to the surroundings, the space, and the other dancers, the choreographic practice became an interaction between what choreographed the dancers and what the dancers choreographed. The interactions between bodies; different materials, such as yarn and personal objects; and thoughts, hopes, and desires were visualised as performative practice through the body.

When the dancers used a photograph of themselves to explore the feeling of «being me now» 
and the feeling of «being me then» (in the picture), they began to create art. The photograph served to connect with a personal discovery that enabled the dancers to express themselves artistically. This implied that the dancer became artistic because of the photograph. The potential that a photograph and other objects had, this affordance (Nelson 2013, 41), was essential to helping the dancers achieve the experience of artistry. By using the objects' affordance in dance, the dancers challenged their boundaries which led to creating meaning and pride.

Using improvisation as a self-determining practice and somatic approach as a possibility to gain contact with embodied experiences (Nadeau and Young 2006), the dancers expressed themselves without being overshadowed by notions of a specific aesthetic and bodily ability. The fact that there was no explicit dance aesthetic to aim for opened the dancers up to develop the aesthetics themselves. Memories and lived experiences were used to explore the body in collaboration with others, rather than the construction of a possible dancing self through imitation. Thus, seeing elderly women in dance has the potential to challenge norms related to dance and the body and can use deconstruction to reformulate alternative knowledge in the context of choreography.

I see improvisation as a practice that implicitly involves an age-critical perspective due to a continuous transformation of the body in time and space. Ageing is a part of a body's transformative process, which is neither fixed, constant, nor measurable. With an unstable subjectivity and no fixed self, there is no body that can decay or be lost through ageing. This approach advocates that ageing is part of a process of being itself (Schweiger 2012, 109).

\section{Writing as an Embodied Way of Thinking}

Immediately following each workshop, I wrote down and reflected upon my experiences and thoughts. This retrospective introspection (Frostling-Henningson 2017, 42) was necessary in order to be able to determine what happened between me and the dancers. The notes served to resonate between the supplemented writing and the choreographic practice and became an embodied way of thinking.

In logbooks handed out at the first workshop, the dancers were asked to write their reflections regarding body, age, and dance based on their experiences with dancing. The initial purpose was to gain a deeper understanding of what dance can do for elderly women and how these women experience artistry. As a researcher, I did not want the dancers' written words to affect me during the process, and for that reason, I relied on the doing that arose in the moment instead of reacting to the written reflections. Hence, the logbooks were collected, and I read them after the project ended.

With humility and excitement, I continued the artistic process by reading the dancers' personal documentation as an echo of collected traces, or as Kim Vincs writes, «I don't translate my dances but I create a new trajectory or line of flight» (Vincs 2019, 111). The voices that their notes created established a presence that did justice to their intentions. After analysing and summarising the notes, I found a reflexivity in their body which seemed to become visible through the documentation. The dancers referred to profound realisations that were emerging through the dance and affecting different layers of their personality. Several dancers described how thinking and reflecting on dance while dancing helped them discover their artistry. This became possible through an unpretentious and permissive environment that was crucial to daring them to explore their inner selves. Overall, I became aware of the importance of the dancers' thinking, dancing, and writing about dancing in a reflexive process in order to gain a deeper understanding of the self, which in turn generated an experience of artistry. 


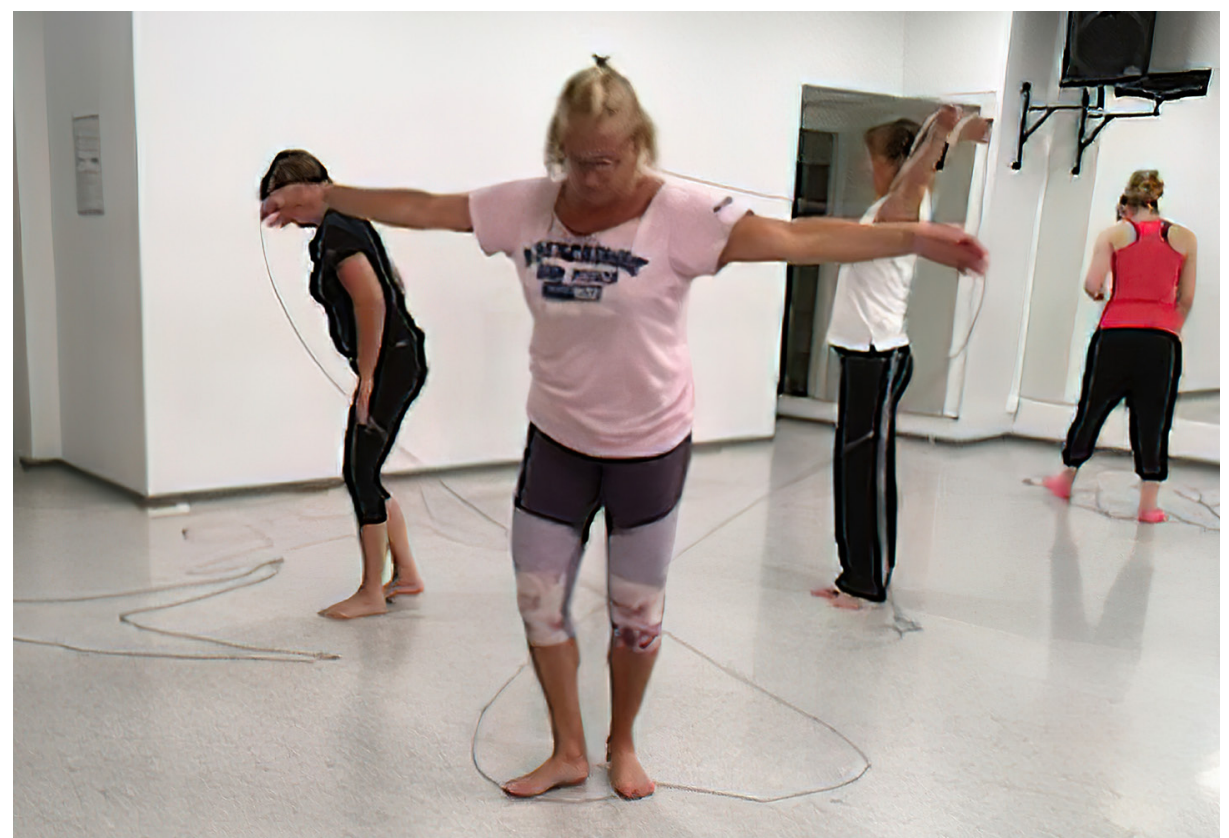

The image is an excerpt from pictures taken during the project (Simonson 2021).

\section{"What I did was not dance, it was art"}

Perceiving artistry in dance was not intuitive, and only emerged during the project. In retrospect, my concern in emphasising a clear distinction between dance as art and dance as physical training contributed to making norms about artistry visible. I took for granted the fact that the dancers could define an artistic value; however, this turned out not to be the case.

The Euro-American dance canon that characterises western culture includes a hierarchical order with a clear definition of who is an artist (or not) and who can define themselves as a dancer (Fensham 2008, 1). When the structure of dance is based on a system of knowledge involving the choreographer as the authority, the dancers consequently experience a distance and a respect for the concept of art. This became clear when I made assumptions about art as being something desirable. By raising awareness of this gap, norms about the accessibility of art became visible and thus were possible to deconstruct.

One dancer reflected on the question, when do you feel artistic in dance? She answered, «I haven't thought about that. I feel like a layman in dance.» At first, this answer surprised me. How was I able to make a strong connection between dance and art so easily while the dancers were not? The dancers implicitly needed permission from me, as a choreographer and representative of the artistic academy, to identify themselves as being artistic.

Later in the project, when the experience of being artistic arose, another dancer chose to distance her practice from dancing by expressing that, «What I did was not dance, it was art.» A sensation of artistry became apparent without associating it with dancing. At this moment, normative notions about who has access to dance in an artistic context became visible. 


\section{Deconstruction of Dance \\ Discourses through Decolonising Methodology}

The decolonising methodology focused on both the dance and the dancer. By making the bodies of elderly women visible as bearers of knowledge of contemporary dance and by giving legitimacy to their experience, assumptions about the young dancer body as a norm was dismantled. I chose to use the decolonising methodology and perspective in a white and westernised dance context to problematise how dance knowledge is produced, how ownership of dance is created (or not), and what and whose knowledge is considered valuable in dance. "Decolonizing methodologies is not a method for revolution in a political sense but provokes some revolutionary thinking about the roles that knowledge, knowledge production, knowledge hierarchies, and knowledge institutions play in decolonization and social transformation» (Tuhiwai Smith 2012, xii).

The dancers and I practiced and discussed a set of normative ideas regarding contemporary dance. For example, the dancers could confidently move with strength, lightness, weight, or stiffness. They were physically able and there was no need for normative body ideals within the dancing space. When the dancers were encouraged to make their own decisions through struggle and self-determination, they developed their self-esteem and ownership. Or as one dancer expressed, «I'm creating something that only I own. That is mine. I make the dance sensual, artistic.» This indicated that experiencing ownership was crucial to achieving artistry. Listening emotionally to the body rather than relying on imitational practices rejects an authoritarian teaching situation (Sö̈t and Viskus 2013).

Another example appeared while experimenting with different identities. One dancer expressed how she could use both traditionally female and male energies in dancing, saying, «Movements are as good as emotions. And they are both the woman and the man in me» (Simonson 2021, 31). When the dancers were allowed to use their experiences without requirements from a normative outside gaze, the feeling of selfdetermination arose and a deconstruction of the female dancer and the dance occurred.

One of the workshops examined the theme of body memory. The dancers explored how early childhood experiences affected the body. Unpleasant memories like, «a tight feeling in the stomach and pressure over the chest,» were used in the dance sessions. This generated new discoveries of dance and the feeling of a memory as ageless. As one dancer expressed, «When I dance, I don't have an age. I can play, be imaginative, creative, funny, serious, and all that doesn't have an age. I feel like all my ages in the dance» (Simonson 2021). In that moment, choreography and dance became a means to negotiate different realities beyond the body moving in space, where ageing is part of a process of being a self and is a subjective creation that is never fixed but constantly changing. With the help of decolonising methodology, the dancers created the feeling of re-establishing the body in dance and defined themselves as artistic.

\section{Conclusion}

The findings show that elderly women's need for personal development and self-realisation is strong regardless of age and is something they can explore by participating in a dance project. By interacting with me and the others, the dancers used their life experiences and creative expressions to investigate dance, embodiment, and their thoughts about ageing and dance. This generated a transformative learning process as well as the feeling of ownership, empowerment, and artistry. With an open and permissive atmosphere, the dancers and I could come together by dancing on equal terms while also developing self-confidence and trust.

By allowing oneself to dance just for the sake of the 
dance itself, a sense of being artistic emerged without consideration for physical ability and requirements. From a researchers' perspective and as part of the group of elderly women, I found a deep confidence in my own artistry. As a result, the gap between artistry and dance was clarified, discussed, and deconstructed. The dancers discovered unknown artistic abilities that they valued higher than they first expected.

I argue that these findings can be understood as a decolonisation of the identity of elderly women within the context of contemporary dance. The group's experiences are visualised, articulated, and re-established as decolonialised embodied knowledge. Ageing is ongoing regardless of age. If considering that dance deconstructs age and age deconstructs dance, an ageing female body can be valued as a resource for further development of contemporary dance.

\section{References}

Barett, Estelle, and Barbara Bolt, eds. 2010. Practice as Research: Approaches to Creative Arts Enquiry. London: Bloomsbury Visual Arts.

Brandstetter, Gabriele. 2007. «Dance as Culture of Knowledge: Body Memory and the Challenge of Theoretical Knowledge.» In Knowledge in Motion: Perspectives of Artistic and Scientific Research in Dance, edited by Gehm, S., Husemann, P., and von Wilcke. K., 37-47. Bielefeld: Transcript Verlag.

Coogan, Jenny. 2016. Practicing Dance: A Somatic Orientation. Berlin: Logos.

Fensham, Rachel. 2008. «Deconstruction and Embodiment: Steps towards the Decolonizing of Dance Discourses.» Discourses in Dance 4, no. 2: 1-16. Frostling-Henningson, Maria. 2017. Kvalitativa metoder: Introspektion, poesi, netnografi, collage och skuggning. Lund: Studentlitteratur.

Klien, Michael. 2008. «Choreography as an Aesthetics of Change.» PhD diss., Edinburgh College of Art,
The University of Edinburgh. Accessed April 6, 2021. https://www.academia.edu/3809926/CHOREOGRAPHY_AS_AN_AESTHETICS_OF_CHA NGE.

Krekula, Arvidson, Heikkinen, Henriksson, and Olsson. 2017. «0n Gray Dancing: Constructions of Age-Normality through Choreography and Temporal Codes.» Journal of Aging Studies 42: 38-45. http://dx.doi.org/10.1016/j.jaging.2017.07.001.

Nadeau, Denise and Alannah Earl Young. 2006. «Educating Bodies for Self-Determination: A Decolonizing Strategy.» Canadian Journal of Native Education 29, no. 1: 87-101.

Nakajima, Nanako and Gabriele Brandstetter. 2017. The Aging Body in Dance: A Cross-Cultural Perspective. New York: Routledge.

Nelson, Robin. 2013. Practice as Research in the Arts: Principles, Protocols, Pedagogies, Resistances. Hampshire: Palgrave Macmillan.

Simonson, Annakarin. 2021. «Att synliggöra marginaliteten äldre kvinnor i dekonstruktion av samtida dansdiskurser med dekoloniserande metodologi - ett konstnärligt, didaktiskt och koreografiskt projekt» [«To Visualize the Marginality of Older Women in Contemporary Dance Discourses with Decolonizing Methodology - an Artistic, Pedagogical and Choreographic Project.»] Master's thesis, Stockholm School of the Arts.

Sööt, Anu and Ele Viskus. 2014. «Contemporary Approaches to Dance Pedagogy - The Challenges of the 21st Century.» Procedia - Social and Behavioral Science, 112: 290-299. Accessed June 30, 2021. https://reader.elsevier.com/reader/sd/ pii/S1877042814011847?token $=3377$ E26598AA02B65390DC5E43BC287B227082FF87173B76F541DB3CC1AFEE6B4FAC78CD35B28152033 DE293572AB592. 


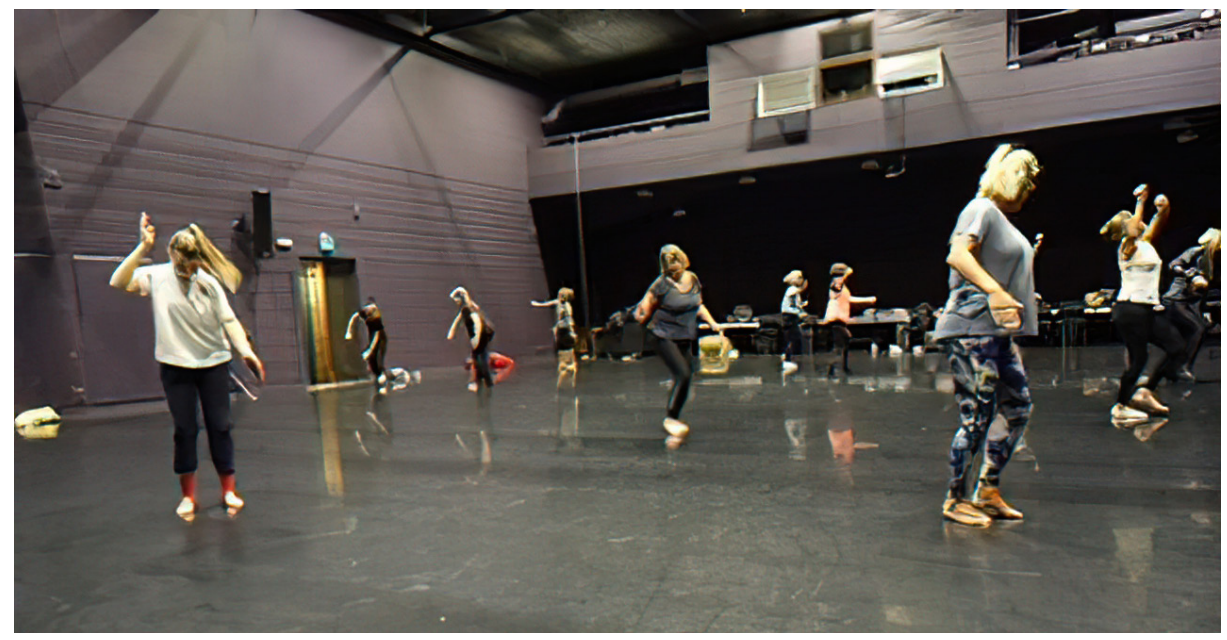

The image is an excerpt from pictures taken during the project (Simonson 2021).

Tuhiwai Smith, Linda. 2012. Decolonizing Methodologies: Research and Indigenous Peoples. Croydon: Zed Books.

Vincs, Kim. 2010. «Rhizome/Myzone: A Case Study in Studio-Based Dance Research.» In Practice as Research: Approaches to Creative Arts Enqui$r y$, edited by Estelle Barrett, and Barbara Bolt, 99-112. London: Bloomsbury Visual Arts.

\section{BIOGRAPHY}

Annakarin Simonson holds a master's in contemporary dance didactics and a teacher's degree in dance from Stockholm University of the Arts. She is active as a dance teacher in contemporary dance, choreography, and improvisation at the Royal Swedish ballet school in Stockholm. She has a special interest in research regarding dialogic artistic and choreographic processes, contemporary dance contexts, somatic approaches and bodily learning. This article is based on her master's thesis from the Master Program in Dance Education in Contemporary Contexts at Stockholm University of the Arts (SKH). Her work has been presented at the dance festival, Tensta dansar.

annakarin.simonson@hotmail.com 